\title{
Response of pepper (Capsicum annum L.) to different sources of microelements on growth, yield and chemical composition under Ras Sudr conditions
}

\author{
Shadia, B. D. Youssif \\ Plant Production Department, Desert Research Center, Cairo, Egypt
}

\begin{abstract}
Pepper plants of CV. California Wonder were grown under saline conditions of Ras Suder Research Station, Desert Research Center in South Sinai Governorate, during autumn growing seasons of 2008 and 2009. Eighteen treatments were: Two method application as nine soil addition treatments; control (without addition), iron ores at rate of (25 and $30 \mathrm{~kg}$./fed.), zinc ore at rate of (15 and $20 \mathrm{~kg}$./fed.) besides interaction treatments. Also, nine foliar spray treatments; control (Water spray), 50 and 100 ppm Fe-EDTA, 50 and 100 ppm Zn-EDTA as well as interaction treatments. The treatments were added 30, 45 and 60 days after transplanting. A split plot design was used. The foliar spray method surpassed than soil addition method, also the interaction treatments with highest level of $\mathrm{Fe}+\mathrm{Zn}$ as foliar spray gave the best values of growth parameters (plant height, No. of branches, shoot fresh and dry weight and leaf area) also, total yield and its components (number of fruits/plant, fruit length, diameter and weight) as well as, chemical composition (total chlorophyll, protein, V.C , nitrogen, phosphorus and potassium, $\mathrm{Ca}$, zinc and iron content of fruits) except $\mathrm{Cl}$ and $\mathrm{Na}$ gave the lowest values with increasing $\mathrm{Fe}+\mathrm{Zn}$ level up to (100 ppm ) concentration.
\end{abstract}

Key words: sweet pepper (growth, yield, chemical composition), soil addition, Foliar application, iron, zinc, saline conditions.

\section{Introduction}

Sweet pepper (Capsicum annum L.) is a member of the solanaceous fruity vegetables group. Its fruits are highly nutritious, rich in vitamins, particularly pro-vitamin-A, vitamin-B, vitamin-C and minerals such as $\mathrm{Ca}, \mathrm{P}, \mathrm{K}$ and $\mathrm{Fe}$. The fruits are widely used for stuffing and salads (El-Bassiony et al., 2010). It is cultivated in Egypt for local consumption and exportation. The soils of South Sinai are highly calcareous and saline. These soils are very poor in nutrients or the nutrients not available to the plants. The irrigation is depends on underground water, most of these water are saline. The use of such water and soils led to decrease in productivity.

The yield of plants depend on many factors, salinity is one of the key factors causing decrease in growth and productivity of crops such as sweet pepper (Muhammad and Rafiq, 2011). In calcareous soils solubility of micronutrients is far less due to high soil $\mathrm{pH}$ and this reduces ability of nutrients uptake by plants (Sayed 2011). Excessive sodium present in the rhizosphere, cause toxic behavior in plant metabolism and physiological droughts; hence plants suffer deficiency of other mineral elements, which are essential for growth (Ahmad and Jabeen, 2005). The growth, yield and ions content significantly reduced in pepper and tomato under salt stress (Hakan et al., 2006 and Ejaz el al., 2011).

Iron is one of the essential plant nutrients and it is necessary to obtain high yield, certain enzymes, proteins and chlorophyll synthesis of red chillies (Briat et al., 2007). In this respect, soil application
(Fe-EDTA at 15 and $20 \mathrm{~kg} / \mathrm{ha}$ ) improved growth parameters of chili crop. Also, recorded highest fruit yield $(10.5 \mathrm{q} / \mathrm{ha})$, ascorbic acid $(178.90 \mathrm{mg} / 100 \mathrm{~g})$ and highest uptake of nitrogen, phosphorus potassium, sulphur and iron (Shivaprasad et. al, 2009). In another study, Malawadi et al., 2003 observed that, application of iron chloride at $12 \mathrm{~kg} / \mathrm{ha}$ recorded hundred fruit weight of chili (198.1 g), yield $(843.86 \mathrm{~kg} / \mathrm{ha})$ and maximum ascorbic acid was $(81.67 \mathrm{mg} / 100 \mathrm{~g})$.

Zinc is essential element for crop production and optimal size of fruit, also zinc has main role in synthesis of proteins, enzyme activating, oxidation, revival reactions and metabolism of carbohydrates, also, it increases the rate of chlorophyll (Ali et al., 2012). Also Shil el al., (2013) found that zinc played significant role in augmenting growth, yield components and yield of chilli. In another study, Hakan et al., 2006 showed that $\mathrm{Zn}$ deficiency in soil significantly reduced growth of pepper, particularly under the high salt conditions. Increases in $\mathrm{Zn}$ application from 2 to $10 \mathrm{mg} / \mathrm{kg}$ soil significantly increased chlorophyll, soluble protein and reduced shoot content of $\mathrm{Na}$ and elevated $\mathrm{K}$ concentration. $\mathrm{Zn}$ also, improved growth and yield of tomato plants cultivated under saline conditions (Gurmani et al., 2012).

Foliar application is immediately deliver nutrients to the tissues and organs of the crop and increase the crop yield, quality and overcome the negative effect of stress conditions (Kolota \& Osinska, 2001 and Anonymous, 2004). In this respect, Hatwar et al., (2003) and Savitha, (2008) found that $0.5 \% \mathrm{Fe}-$ EDTA foliar spray recorded increase in fruit yield of 
chili (10.5 q/ha), plant height $(\mathrm{cm})$, number of branches/plants, ascorbic acid (178.90 mg/100 g) and uptake of $\mathrm{N}$ and $\mathrm{P}$. As for, significant improvement was observed in the number and weight of fruits and size of chili or sweet pepper, chlorophyll and protein contents, due to the foliar application of trace elements ( $\mathrm{Fe}, \mathrm{Cu}, \mathrm{Mn}, \mathrm{Zn}, \mathrm{B}$ and $\mathrm{Mo}$ ) alone or in combination (Shivaprsad et al, 2009). In another study, Agarwal et al., (2010) reported that application of $\mathrm{FesO}_{4}$ at 0.5 per cent on tomato as foliar spray, increased plant height $(\mathrm{cm})$, number of branches, leaf area, fresh and dry weight content of shoot, also produced higher yield (77.39 t/ha) and maximum uptake of $\mathrm{N}, \mathrm{P}, \mathrm{K}, \mathrm{Zn}$ and Fe.

The foliar application of zinc at conc. $3.0 \mathrm{ppm}$ gave highest number of fruits/plant, dry fruit yield of chilies and tomato, net income and benefit cost ratio (Singh and Tiwari 2013). Also, Ali et al., (2013) found that $\mathrm{Znso}_{4}$ conc. $0.50 \%$ foliar spray exhibited the increase yield of chilli and tomato. In another study, Ahmed et al., (2011) in Kafr El-Zayat, found that increasing of zinc conc. up to $300 \mathrm{ppm}$ increased the vegetative growth of potato plants, total yield (ton/fed.), quality, protein and dry matter $\%$ as well as $\mathrm{N}, \mathrm{P}, \mathrm{K}$ and $\mathrm{Zn} \%$.

The aim of this study was to cultivate sweet pepper under saline Ras Sudr conditions in South Sinai Governorate to elucidate the effect of iron and zinc applications by two methods (soil addition or foliar spray) with different rates of application in order to improve growth, yield and quality of sweet pepper CV. California Wonder under saline conditions.

\section{Materials and Methods}

The present work was carried out during the two successive autumn seasons of 2008 and 2009 at Ras Sudr Research Station, Desert Research Center in South Sinai Governorate, to study the effect of two methods application (soil addition and foliar spray) with two rates of some microelements ( $\mathrm{Fe}$ and $\mathrm{Zn}$ ) and the combination between them in addition to control treatment on growth, yield and chemical composition of sweet pepper (Capsicum annum L.,) CV. California wonder. The seeds were sown in 209 cell foam trays filled with peat moss: vermiculite: sandy soil $(1: 1: 1 \mathrm{v} / \mathrm{v} / \mathrm{v})$ media. The trays were kept in the greenhouse and carried by regular practices for seedlings production. Uniform pepper seedlings were transplanted to the field at the age of 55 days in $24^{\text {th }}$ July and $5^{\text {th }}$ August during first and second seasons respectively. The experiment was arranged in a split plot design with three replicates. Methods of application were arranged within the main plots, while treatments of $\mathrm{Fe}$ and $\mathrm{Zn}$ were distributed randomly in the sub-plots. Drip irrigation system was applied. The source of saline water (about 3700-4000 ppm) from underground well. The experimental area was $10.5 \mathrm{~m}^{2}$ (irrigation line long was $10.5 \mathrm{~m}$ and one meter width between lines) the distance between plants was $30 \mathrm{~cm}$, normal agriculture practices were carried out as recommended by ministry of agriculture.

\section{The experimental treatments:-}

Eighteen treatments were investigated as:

(A) Soil addition treatments were added three times at 30, 45 and 60 days after transplanting.

- Control (without addition), iron ore was added at rates of $25 \mathrm{~kg}$. and $30 \mathrm{~kg}$./fed., while zinc ore was added at rate of $15 \mathrm{~kg}$. and $20 \mathrm{~kg}$./fed. and combination between them (iron ore at rate of 25 $\mathrm{kg} . / \mathrm{fed}$ or $30 \mathrm{~kg}$./fed. with $15 \mathrm{~kg}$. /fed. zinc ore, also iron ore at rate $25 \mathrm{~kg}$. or $30 \mathrm{~kg}$. /fed. with 20 $\mathrm{kg}$. zinc ore).

-The interaction treatments were: soil addition methods $\mathrm{x}$ micronutrients treatments.

(B) Foliar spray treatments were applied three times at 30, 45 and 60 days after transplanting.

- Control (water foliar spray), $50 \mathrm{ppm}$ and $100 \mathrm{ppm}$ Fe-EDTA, also Zn- EDTA were added at concentrations of $50 \mathrm{ppm}$ and $100 \mathrm{ppm}$ and combination between them (50 ppm and $100 \mathrm{ppm}$ Fe-EDTA with 50 ppm Zn- EDTA, also50 ppm and 100 ppm Fe-EDTA with 100 ppm ZnEDTA). - The interaction treatments were: foliar spray methods $\mathrm{x}$ micronutrients treatments.

Iron and zinc ores were divided to three equal parts and mixed with sand before application to the soil to ensure the uniform distribution for the plants. While, 50 and 100 ppm foliar spray of $\mathrm{Fe}$ and $\mathrm{Zn}$ EDTA were given after dissolving the requisite quantity of fertilizer in water.

\section{* EDTA - Ethylene Diamine Tetra Acetic Acid. \\ * Iron in form Magnatic iron ore (Mio), contained $\left(4.3 \% \mathrm{SiO}_{4}, 48.2 \% \quad \mathrm{Fe}_{3} \mathrm{O}_{4}, \mathbf{1 7 . 3 \%} \quad \mathrm{FeO}, \mathbf{2 6 . 7 \%}\right.$ $\mathrm{Fe}_{2} \mathrm{O}_{3}, 2.6 \% \mathrm{mgO}$ and $0.3 \% \mathrm{CaO}$ ) obtained from El-Ahram Company for Mining and Natural Fertilizers, Giza, Egypt and zinc ore (63.0- 55.0 $\% \mathrm{MnO}_{2}, 5.00-8.00 \% \mathrm{SiO}_{2}, 7.00-9.00 \% \mathrm{Fe}_{2} \mathrm{O}$, 6.00- 7.00\% CaO, 3.00- 35.0\% $\mathrm{MgO}, \quad 0.40-$ $1.00 \% \mathrm{Na}_{2} \mathrm{O}, 0.10-0.30 \% \mathrm{~K}_{2} \mathrm{O}, 35.0-40.0 \% \mathrm{Mn}$, MnO \%MnO) obtained from Nasr Mining Company.}

NPK fertilizers were added to the experiment as soil application, $300 \mathrm{~kg}$. calcium supper phosphate $\left(15.5 \% \mathrm{P}_{2} 0_{5}\right)$ was added month before transplanting, while ammonium sulphate $(20.5 \% \mathrm{~N})$ and potassium sulphate $\left(48 \% \mathrm{~K}_{2} 0\right)$ were added twice at rate of 300 and $200 \mathrm{~kg}$. respectively. The quantities divided into two equal parts which were added at 15 and 45 days after transplanting respectively.

\section{Soil Characteristics of the experimental site:}

The soil of the experimental site is highly calcareous and saline. Soil samples were taken from 0-30 cm and 30-60 depth, which were collected from 
the experimental area before initiating the experiment. The samples were analyzed for physical and chemical properties where determined according to Piper (1950) and Jackson (1967) respectively, as shown in Tables (A \& B). Also, analysis of saline irrigation water is presented in Table (C) according to Richards (1954).

Table A. Mechanical properties of the experimental soil.

\begin{tabular}{llllllll}
\hline $\begin{array}{l}\text { Soil depth } \\
(\mathrm{cm})\end{array}$ & $\mathrm{CaCO}_{3} \%$ & $\begin{array}{l}\text { Coarse sand } \\
(0.5-1 \mathrm{~mm})\end{array}$ & $\begin{array}{l}\text { Fine sand } \\
(0.1-0.25 \\
\mathrm{mm})\end{array}$ & $\begin{array}{l}\text { Silt } \\
(0.002-0.05 \\
\mathrm{mm})\end{array}$ & $\begin{array}{l}\text { Total sand } \\
(0.1-1)\end{array}$ & $\begin{array}{l}\text { Clay } \\
(0-002)\end{array}$ & $\begin{array}{l}\text { Class texture } \\
\%\end{array}$ \\
\hline $0-30$ & 56.99 & 53.68 & 27.60 & 8.05 & 81.28 & 10.79 & $\begin{array}{l}\text { Sandy loam } \\
\text { Sandy loam }\end{array}$ \\
\hline $30-60$ & 52.48 & 23.74 & 62.34 & 7.59 & 86.08 & 6.33 & Sand \\
\hline
\end{tabular}

Table B. Chemical properties of the experimental soil.

\begin{tabular}{|c|c|c|c|c|c|c|c|c|c|c|}
\hline \multirow{2}{*}{$\begin{array}{l}\text { Soil } \\
\text { depth } \\
(\mathrm{cm})\end{array}$} & \multirow[t]{2}{*}{$\mathrm{pH}$} & \multirow[t]{2}{*}{$\mathrm{dS} / \mathrm{m}$} & \multicolumn{4}{|c|}{ Soluble anions $(\mathrm{meq} / \mathrm{L})$} & \multicolumn{4}{|c|}{ Soluble Cations (meq/L) } \\
\hline & & & $\mathrm{CO}_{3}^{--}$ & $\mathrm{HCO}_{3}$ & $\mathrm{SO}_{4}^{--}$ & $\mathrm{Cl}^{-}$ & $\mathrm{Ca}^{++}$ & $\mathrm{Mg}^{++}$ & $\mathrm{Na}^{+}$ & $\mathrm{K}^{+}$ \\
\hline $0-30$ & 7.7 & 4.77 & 0.00 & 6.00 & 10.50 & 31.20 & 24.00 & 11.00 & 10.52 & 2.18 \\
\hline $30-60$ & 7.4 & 4.16 & 0.00 & 3.00 & 16.10 & 22.50 & 16.83 & 6.00 & 17.80 & 0.09 \\
\hline
\end{tabular}

Table C. Chemical analysis of irrigation water.

\begin{tabular}{|c|c|c|c|c|c|c|c|c|c|}
\hline \multicolumn{6}{|c|}{ Soluble anions (meq/L) } & \multicolumn{4}{|c|}{ Soluble Cations (meq/L) } \\
\hline $\mathrm{pH}$ & $\mathrm{EC}$ & $\mathrm{CO}_{3}^{--}$ & $\mathrm{HCO}_{3}$ & $\mathrm{SO}_{4}^{--}$ & $\mathrm{Cl}^{-}$ & $\mathrm{Ca}^{++}$ & $\mathrm{Mg}^{++}$ & $\mathrm{Na}^{+}$ & $\mathrm{K}^{+}$ \\
\hline 6.8 & 7.03 & 0.00 & 2.50 & 21.23 & 41.28 & 4.50 & 13.43 & 47.05 & 0.12 \\
\hline
\end{tabular}

Data were recorded for the following characters:

Five plants were randomly selected from each experimental area at the beginning of the flowering stage and the following data were recorded:

\section{A. Vegetative Growth:}

1- Plant height $(\mathrm{cm})$.

2-Leaf area

3- Number of branches/plant.

4- Fresh and dry weight of shoot/plant (g).

\section{B. Yield and its components:}

Green pepper fruits were harvested at maturity stage and collected every week from each plot for calculation the total fruits (8times). Samples for determination physical characters of fruit quality were randomly taken from the third harvest time, and the following data were recorded.

1- Average of fruit length/plant $(\mathrm{cm})$.

2- Average of fruit diameter $(\mathrm{cm})$

3- Average of fruit weight (g).

5- Fruit yield per plant (g)

6- Total yield as ton/fed.

\section{C-Chemical content}

Leaf area was measured using leaf area meter (Model 3100 Area Meter. Li- Cor. Inc. Lincoln, Nebrask. USA). Also, total chlorophyll content was determined in fully expanded leaves as third and fourth leaves which measured as SPAD units using Minolta SPAD-501 chlorophyll Meter (Minolta Co. Ltd., Japan) according to A.O.A.C. (1990). Vitamin $\mathrm{C}$ content was determined in the fruit as $\mathrm{mg} / 100 \mathrm{~g}$ fresh weight according to method described in A.O.A.C. (1990). The minerals content in leaves were estimated using the wet ash procedure for the dry powdered samples (Johnson and Uirich, 1959), total nitrogen was determined by modified micro kjeldahl according to Huphries (1965). Potassium, sodium and calcium contents were determined using flame photometer according to methods of Brown and Lilland (1964). Chloride was also determined by method described by Richards (1954). Phosphorus was determined by modified spectrophotometer method according to Rowell (1994). In addition, iron and zinc were determined by using atomic-absorption as described by Chapman and Pratt (1982).

\section{Statistical Analysis:}

All obtained data were subjected to statistical analysis of variances of the split plot design according to the procedure outline. by Gomez and Gomez (1984).

\section{Results and Discussion}

\section{A- Vegetative growth:}

Vegetative growth of plants are expressed as plant height, shoot fresh and dry weight, No. of branches/plant, leaf area and total chlorophyll which are presented in Tables (3 and 4).

\section{A.1. Method of application:}

Soil addition or foliar spray application of $\mathrm{Fe}$ and $\mathrm{Zn}$ increased growth characters significantly when compare each of method with its control treatment. Soil addition control is without Fe and $\mathrm{Zn}$ addition, and foliar spray control is water foliar spray. Foliar spray application increased growth characters of sweet pepper plants (plant height, shoot fresh and dry weight, No. of branches, leaf area and total chlorophyll) significantly when compared to soil addition application of $\mathrm{Fe}$ and $\mathrm{Zn}$ except No. of 
branches/plant, there is no significant difference between method of application in first season only, while leaf area has no significant difference in the second season only. These results are presented in Tables (3 and 4) in both growing seasons. The data agree with results obtained by Agarwal et al. 2010; Ali et al. 2013; Naga et al. 2013; Singh and Tiwari 2013 on tomato. These results may be due to foliar feeding of micronutrients helps uptake of essential minerals through the root system is restricted due to salt stress (El-Fouly and Abou El-Nour, 1998). Also, may be due to fast deliver nutrients to the tissues and organs crop by foliar application and increase the growth of plant and overcome the negative effect of stress conditions ( Kolota and Osinska, 2001 and Anonymous, 2004).

Improvement in growth characters as a result of application micronutrients as foliar spray might be due to the enhancement of photosynthetic pigments expressed in chlorophyll and other metabolic activity which leads to an increase in various plant metabolites responsible for cell division and elongation. The least values on growth characters were recorded with spraying water or without addition (control). Salinity is one of the key factors causing decrease in growth and productivity of almost all the crops such as sweet pepper (Hakan $\boldsymbol{e t}$ al, 2006 and Muhammad and Rafiq 2011).

Table 3. Effect of some micronutrients on vegetative growth parameters of sweet pepper through growing autumn seasons.

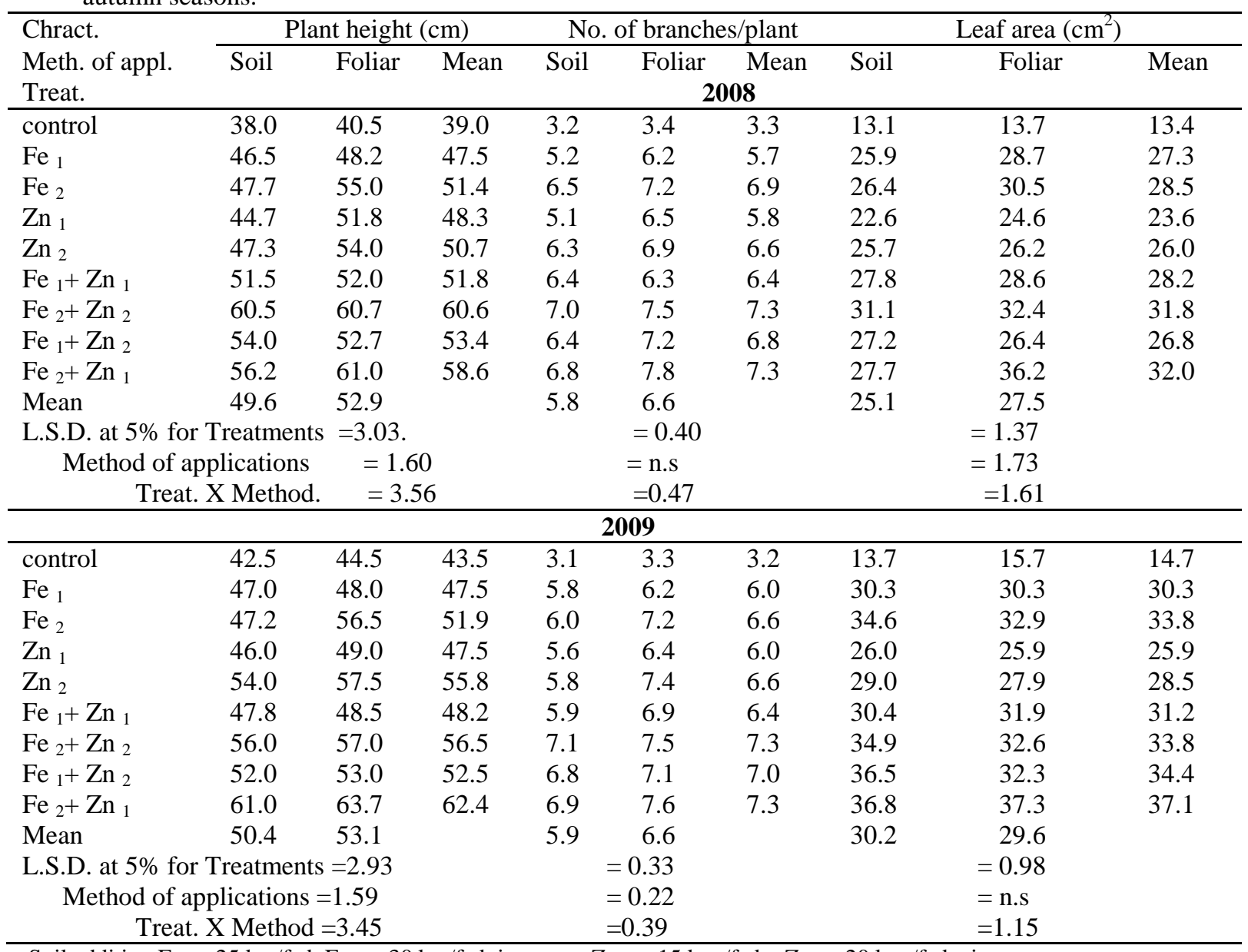

Soil addition $\mathrm{Fe}_{1}=25 \mathrm{~kg}$./fed, $\mathrm{Fe}_{2}=30 \mathrm{~kg}$./fed. iron ore, $\mathrm{Zn}{ }_{1}=15 \mathrm{~kg}$. $/$ fed., $\mathrm{Zn}{ }_{2}=20 \mathrm{~kg}$. $/ \mathrm{fed}$. zinc ore

Foliar addition $\mathrm{F}_{1}=50 \mathrm{ppm}, \mathrm{F}_{2}=100 \mathrm{ppm}$ iron-EDTA, $\mathrm{Zn}_{1}=50 \mathrm{ppm}, \mathrm{Zn}_{2}=100 \mathrm{ppm} Z$ inc-EDTA

\section{A.2. Fe and $\mathrm{Zn}$ treatments:}

The results are shown in Tables ( 3 and 4 ) cleared that vegetative growth characters (plant height, No. of branches/plant, shoot fresh and dry weight, leaf area and total chlorophyll) increased with increasing rate of $\mathrm{Fe}$ soil addition from 25 to $30 \mathrm{~kg}$./fed. significantly when compare to control treatment. Also, Fe EDTA foliar spray increased vegetative growth with increasing dose of application from 50 up to $100 \mathrm{ppm}$ significantly when compare to water spray treatment.

The same trend observed with zinc application, growth characters values increased with increasing rate of zinc are from 15 up to $20 \mathrm{~kg}$./fed. Significantly when compared to control treatment. Also, Zn-EDTA foliar spray increased the vegetative growth with increasing rate of application from 50 up to $100 \mathrm{ppm}$ when compared to water spray treatment. Data which are presented in Tables (3\&4) showed 
that sweet pepper plants treated with $\mathrm{Fe}$ gave the highest values of all measured growth parameters following by $\mathrm{Zn}$ application in both growing seasons when compared to single treatments. The higher dose of single Fe treatments recorded the highest growth characters values of sweet pepper than $\mathrm{Zn}$ ore. The combination treatments of $\mathrm{Fe}$ and $\mathrm{Zn}$ surpassed than single treatments on growth characters of sweet pepper. The best figures of growth characters revealed with combination treatments $\left(\mathrm{Fe}_{2}+\mathrm{Zn}_{1}\right)$ and $\left(\mathrm{Fe}_{2}+\mathrm{Zn}_{2}\right)$ respectively, when compare to all other treatments. In calcareous soils solubility of micronutrient is far less due to high soil $\mathrm{pH}$. The least values on growth characters were recorded with control treatment (no soil addition of $\mathrm{Fe}$ and $\mathrm{Zn}$ and water foliar spray). The obtained results were in agreement with those obtained by Hakan et al., 2006 and Shil et al., 2013 on pepper and Ejaz et al., 2011 on tomato. The results may be due to iron deficiency which causing disorder affecting on plant, chiefly associated with high $\mathrm{PH}$ of soils. Also, iron is necessary for photosynthesis, it is present as an enzyme cofactor in plants, also is important in the metabolic path way (Briat et al., 2007). The increasing of growth characters of sweet pepper plants may be due to application of zinc which plays an important role in plant physiology where it activates some enzyme and activate growth of plant (Hakan et al., 2006 and Ali et al., 2012).

Table 4. Effect of some micronutrients on vegetative growth parameters of sweet pepper through growing autumn seasons.

\begin{tabular}{|c|c|c|c|c|c|c|c|c|c|}
\hline \multirow{2}{*}{$\begin{array}{l}\text { Chract. } \\
\text { Meth. of } \\
\text { appl. }\end{array}$} & \multicolumn{3}{|c|}{ Fresh weight of shoot (gm) } & \multicolumn{3}{|c|}{ Dry weight of shoot (gm) } & \multicolumn{3}{|c|}{ Total chlorophyl } \\
\hline & Soil & Foliar & Mean & Soil & Foliar & Mean & Soil & Foliar & Mean \\
\hline Treat. & \multicolumn{9}{|c|}{2008} \\
\hline control & 122.5 & 126.5 & 124.5 & 26.3 & 41.5 & 33.9 & 40.9 & 42.9 & 41.9 \\
\hline $\mathrm{Fe}_{1}$ & 193.0 & 239.0 & 216.0 & 43.7 & 48.0 & 45.9 & 47.5 & 50.5 & 49.0 \\
\hline $\mathrm{Fe}_{2}$ & 277.5 & 280.0 & 278.8 & 54.3 & 56.3 & 55.3 & 57.4 & 59.1 & 58.3 \\
\hline $\mathrm{Zn}_{1}$ & 199.0 & 247.5 & 223.3 & 42.0 & 44.3 & 43.2 & 52.0 & 52.2 & 52.1 \\
\hline $\mathrm{Zn}_{2}$ & 249.5 & 272.8 & 261.2 & 52.0 & 54.7 & 53.4 & 54.3 & 54.7 & 54.5 \\
\hline $\mathrm{Fe}_{1}+\mathrm{Zn}_{1}$ & 239.0 & 259.0 & 249.0 & 52.0 & 53.7 & 52.9 & 47.9 & 55.4 & 51.7 \\
\hline $\mathrm{Fe}_{2}+\mathrm{Zn}_{2}$ & 279.2 & 282.0 & 280.6 & 55.3 & 59.7 & 57.5 & 57.4 & 59.4 & 58.4 \\
\hline $\mathrm{Fe}_{1}+\mathrm{Zn}_{2}$ & 227.5 & 259.0 & 243.3 & 50.0 & 52.7 & 51.4 & 54.3 & 57.3 & 55.8 \\
\hline $\mathrm{Fe}_{2}+\mathrm{Zn}_{1}$ & 295.5 & 288.2 & 291.9 & 56.0 & 60.0 & 58.0 & 60.1 & 61.0 & 60.6 \\
\hline Mean & 231.4 & 250.4 & & 47.6 & 52.3 & & 52.4 & 54.7 & \\
\hline \multicolumn{4}{|c|}{ L.S.D. at $5 \%$ for Treatments $=12.42$} & \multicolumn{3}{|c|}{$=2.61$} & \multicolumn{3}{|c|}{$=2.20$} \\
\hline \multicolumn{2}{|c|}{ Method of applications } & \multicolumn{2}{|c|}{$=11.80$} & \multicolumn{3}{|c|}{$=2.70$} & \multicolumn{3}{|c|}{$=1.70$} \\
\hline \multicolumn{2}{|c|}{ Treat. X Method. } & \multicolumn{2}{|c|}{$=14.61$} & \multicolumn{3}{|c|}{$=3.06$} & \multicolumn{3}{|c|}{$=\mathrm{n} . \mathrm{s}$} \\
\hline \multicolumn{10}{|c|}{2009} \\
\hline control & 147.5 & 156.3 & 151.9 & 25.2 & 27.4 & 26.3 & 44.7 & 46.7 & 45.7 \\
\hline $\mathrm{Fe}_{1}$ & 252.5 & 259.5 & 256.0 & 48.3 & 51.3 & 49.8 & 54.5 & 55.4 & 55.0 \\
\hline $\mathrm{Fe}_{2}$ & 282.3 & 287.5 & 284.9 & 50.9 & 57.0 & 54.0 & 58.0 & 58.4 & 58.2 \\
\hline $\mathrm{Zn}_{1}$ & 234.0 & 266.5 & 250.3 & 35.5 & 42.3 & 38.9 & 48.4 & 53.0 & 50.7 \\
\hline $\mathrm{Zn}_{2}$ & 241.0 & 294.0 & 267.5 & 53.1 & 56.5 & 54.8 & 52.3 & 52.5 & 52.4 \\
\hline $\mathrm{Fe}_{1}+\mathrm{Zn}_{1}$ & 255.0 & 260.3 & 257.7 & 47.5 & 52.7 & 50.0 & 54.8 & 56.6 & 55.7 \\
\hline $\mathrm{Fe}_{2}+\mathrm{Zn}_{2}$ & 284.5 & 288.8 & 286.7 & 52.3 & 53.7 & 53.0 & 59.2 & 58.8 & 59.0 \\
\hline $\mathrm{Fe}_{1}+\mathrm{Zn}_{2}$ & 274.8 & 287.5 & 281.2 & 45.0 & 47.8 & 46.4 & 51.4 & 54.7 & 53.1 \\
\hline $\mathrm{Fe}_{2}+\mathrm{Zn}_{1}$ & 279.5 & 295.0 & 287.3 & 45.5 & 58.0 & 51.8 & 53.8 & 62.3 & 58.1 \\
\hline Mean & 250.1 & 266.1 & & 43.3 & 49.6 & & 53.0 & 55.4 & \\
\hline \multicolumn{4}{|c|}{ L.S.D. at $5 \%$ for Treatments $=9.91$} & \multicolumn{3}{|c|}{$=2.43$} & \multicolumn{3}{|c|}{$=1.54$} \\
\hline \multicolumn{2}{|c|}{ Method of applications } & \multicolumn{2}{|l|}{$=4.17$} & \multicolumn{3}{|c|}{$=1.72$} & \multicolumn{3}{|c|}{$=1.99$} \\
\hline \multicolumn{2}{|c|}{ Treat. X Method } & \multicolumn{2}{|l|}{$=11.65$} & \multicolumn{3}{|c|}{$=2.86$} & \multicolumn{3}{|c|}{$=2.13$} \\
\hline
\end{tabular}

Soil addition $\mathrm{Fe}_{1}=25 \mathrm{~kg}$./fed, $\mathrm{Fe}_{2}=30 \mathrm{~kg}$./fed. iron ore, $\mathrm{Zn}_{1}=15 \mathrm{~kg}$. $/$ fed., $\mathrm{Zn}_{2}=20 \mathrm{~kg}$. /fed. zinc ore

Foliar addition $\mathrm{F}_{1}=50 \mathrm{ppm}, \mathrm{F}_{2}=100 \mathrm{ppm}$ iron-EDTA, $\mathrm{Zn}_{1}=50 \mathrm{ppm}, \mathrm{Zn}_{2}=100 \mathrm{ppm}$ Zinc-EDTA

\section{A.3. The interaction effect:}

Data revealed in Tables ( 3 and 4) indicated that the interaction treatments ( $\mathrm{Fe}$ and $\mathrm{Zn}$ ) of foliar spray surpassed than interaction soil addition treatments with ( $\mathrm{Fe}$ and $\mathrm{Zn}$ ) in growth characters of sweet pepper. The combination treatment $\mathrm{Fe}_{2}+\mathrm{Zn}_{1}(30 \mathrm{~kg} . /$ $\mathrm{Fe}$ ore $+15 \mathrm{~kg} . / \mathrm{Zn}$ ore ) gave the highest values of growth characters (plant height, No. of branches/plant, shoot fresh and dry weight, leaf area and total chlorophyll) than the other soil addition treatments. Also, 100 ppm Fe-EDTA+50 ppm ZnEDTA treatments gave the highest values of growth characters when compared to others foliar spray treatments and all soil addition treatments.

The results are true in both growing seasons. The increases values of growth characters were 
significant with interaction treatments when compare to control treatment, except total chlorophyll values which have no significant differences between interaction treatments. The observed improvement in vegetative growth results of sweet pepper plants may be due to the combination effects of $\mathrm{Fe}$ and $\mathrm{Zn}$ treatments. The results are in accordance with the results obtained by Hatwar et al., 2003.

\section{B . Yield and it's components:}

Yield and it's components of sweet pepper are illustrated in Tables (5and 6) as total yield, No. of fruits/plant fruit length and diameter as well as fruit weight.

\section{B . 1 . Method of application:}

The results presented in Tables (5 and 6) show that soil addition of $\mathrm{Fe}$ and $\mathrm{Zn}$ or foliar spray gave significant influence on yield and it's components when compared with control treatments. Foliar spray of $\mathrm{Fe}$ and $\mathrm{Zn}$ enhanced the positive effect than soil addition method and gave better values of yield and it's components of sweet pepper (total yield, No. of fruits/p. fruit length and diameter and fruit weight). These results are true in both growing seasons. The improvement of sweet pepper yield and it's components with foliar spray application may be due to immediate supply of nutrients to the tissues and organs of crop and increase the crop yield, quality and overcome the negative effect of stress conditions (Kolota and Osinska 2001 in field vegetables and Anonymous 2004). The obtained results in the same line of those obtained by Hatwar et al. 2003; Shil $\boldsymbol{e t}$ al., 2013 on pepper and Ali, et al., 2013; Naga $\boldsymbol{e t}$ al., 2013; Singh and Tiwari 2013 on tomato. Also, these results may be due to foliar feeding of micronutrients which helps uptake of certain essential mineral through the root system which suffer from salt stress due to salt stress.

\section{B . 2. Fe and $\mathrm{Zn}$ treatments}

Data Presented in Tables (5 and 6) showed that application of $\mathrm{Fe}$ or $\mathrm{Zn}$ increased total yield and its components: fruit length, diameter and fruit weight, as well as number and weight of fruits/plant significantly when compared to control treatment. The values of characters increased with increasing rate of $\mathrm{Fe}$ or $\mathrm{Zn}$ application, either as soil addition of iron ore (25 and $30 \mathrm{Kg}$./Fed.) or zinc ore (15 and 20 $\mathrm{Kg} . / \mathrm{Fed}$ ) or as foliar spray, Fe-EDTA (50 and 100 ppm) or Zn-EDTA (50 and 100 ppm).

Table 5. Effect of some micronutrients on fruits yield and quality of sweet pepper through growing autumn seasons.

\begin{tabular}{|c|c|c|c|c|c|c|c|c|c|}
\hline \multirow{2}{*}{$\begin{array}{l}\text { Charact } \\
\text { Meth. of } \\
\text { appl. }\end{array}$} & \multicolumn{3}{|c|}{ Length of fruit (cm) } & \multicolumn{3}{|c|}{ Diameter of fruit $(\mathrm{cm})$} & \multicolumn{3}{|c|}{ Weight of fruit $(\mathrm{g})$} \\
\hline & Soil & Foliar & Mean & Soil & Foliar & Mean & Soil & Foliar & Mean \\
\hline Treat. & \multicolumn{9}{|c|}{2008} \\
\hline control & 3.05 & 3.25 & 3.15 & 2.90 & 3.10 & 3.00 & 24.40 & 26.50 & 25.45 \\
\hline $\mathrm{Fe}_{1}$ & 5.42 & 6.53 & 5.98 & 4.15 & 4.95 & 4.55 & 30.03 & 35.07 & 32.55 \\
\hline $\mathrm{Fe}_{2}$ & 6.56 & 7.00 & 6.78 & 5.65 & 5.77 & 5.71 & 44.10 & 45.00 & 44.55 \\
\hline $\mathrm{Zn}_{1}$ & 6.33 & 6.78 & 6.56 & 4.95 & 5.70 & 5.33 & 41.93 & 42.17 & 42.05 \\
\hline $\mathrm{Zn}_{2}$ & 6.43 & 6.90 & 6.67 & 5.15 & 5.87 & 5.51 & 42.07 & 42.43 & 42.25 \\
\hline $\mathrm{Fe}_{1}+\mathrm{Zn}_{1}$ & 6.65 & 6.77 & 6.71 & 5.50 & 6.38 & 5.94 & 36.27 & 44.37 & 40.32 \\
\hline $\mathrm{Fe}_{2}+\mathrm{Zn}_{2}$ & 6.87 & 7.05 & 6.96 & 5.80 & 6.53 & 6.17 & 44.40 & 51.10 & 47.75 \\
\hline $\mathrm{Fe}_{1}+\mathrm{Zn}_{2}$ & 6.53 & 7.03 & 6.78 & 5.28 & 6.27 & 5.78 & 41.07 & 49.53 & 45.30 \\
\hline $\mathrm{Fe}_{2}+\mathrm{Zn}_{1}$ & 6.57 & 7.32 & 6.95 & 6.45 & 6.68 & 6.57 & 43.63 & 52.60 & 48.12 \\
\hline Mean & 6.05 & 6.51 & & 5.09 & 5.69 & & 38.66 & 43.20 & \\
\hline \multicolumn{4}{|c|}{ L.S.D. at $5 \%$ for Treatments $=0.26$} & \multicolumn{3}{|c|}{$=0.30$} & \multicolumn{3}{|c|}{$=2.25$} \\
\hline \multicolumn{3}{|c|}{ Method of applications $=$} & $=0.45$ & \multicolumn{3}{|c|}{$=0.31$} & \multicolumn{3}{|c|}{$=2.18$} \\
\hline \multirow{2}{*}{\multicolumn{4}{|c|}{ Treat. X Method. }} & \multirow{2}{*}{\multicolumn{3}{|c|}{$\begin{array}{c}=0.36 \\
2009\end{array}$}} & \multicolumn{3}{|c|}{$=2.64$} \\
\hline & & & & & & \multicolumn{4}{|c|}{2009} \\
\hline control & 3.20 & 3.40 & 3.30 & 3.90 & 4.20 & 4.05 & 25.23 & 27.23 & 26.23 \\
\hline $\mathrm{Fe}_{1}$ & 6.27 & 6.60 & 6.44 & 5.87 & 5.97 & 5.92 & 32.80 & 35.03 & 33.92 \\
\hline $\mathrm{Fe}_{2}$ & 7.25 & 7.35 & 7.30 & 6.00 & 6.12 & 6.06 & 39.03 & 40.70 & 39.87 \\
\hline $\mathrm{Zn}_{1}$ & 6.20 & 6.90 & 6.55 & 5.45 & 5.70 & 5.58 & 34.67 & 38.73 & 36.70 \\
\hline $\mathrm{Zn}_{2}$ & 6.60 & 7.30 & 6.95 & 6.00 & 6.18 & 6.09 & 36.67 & 39.73 & 38.20 \\
\hline $\mathrm{Fe}_{1}+\mathrm{Zn}_{1}$ & 6.53 & 6.93 & 6.73 & 6.00 & 6.15 & 6.08 & 37.90 & 39.10 & 38.50 \\
\hline $\mathrm{Fe}_{2}+\mathrm{Zn}_{2}$ & 7.27 & 7.47 & 7.37 & 6.38 & 6.42 & 6.40 & 49.83 & 50.37 & 50.10 \\
\hline $\mathrm{Fe}_{1}+\mathrm{Zn}_{2}$ & 6.25 & 7.00 & 6.63 & 6.00 & 6.25 & 6.13 & 40.53 & 42.60 & 41.57 \\
\hline $\mathrm{Fe}_{2}+\mathrm{Zn}_{1}$ & 7.28 & 7.53 & 7.41 & 6.35 & 6.60 & 6.48 & 40.73 & 53.07 & 46.90 \\
\hline Mean & 6.31 & 6.72 & & 5.787 & 5.95 & & 37.49 & 40.73 & \\
\hline \multicolumn{4}{|c|}{ L.S.D. at $5 \%$ for Treatments $=0.51$} & \multicolumn{3}{|c|}{$=0.41$} & \multicolumn{3}{|c|}{$=3.13$} \\
\hline \multicolumn{3}{|c|}{ Method of applications $=$} & \multirow{2}{*}{$\begin{array}{l}=\mathrm{n} . \mathrm{s} \\
=\mathrm{n} . \mathrm{s}\end{array}$} & \multicolumn{3}{|c|}{$=0.17$} & \multicolumn{3}{|c|}{$=2.82$} \\
\hline \multicolumn{3}{|c|}{ Treat. X Method. } & & \multicolumn{3}{|c|}{$=\mathrm{n} \cdot \mathrm{s}$} & \multicolumn{3}{|c|}{$=3.68$} \\
\hline
\end{tabular}

Soil addition $\mathrm{Fe}_{1}=25 \mathrm{~kg}$./fed, $\mathrm{Fe}_{2}=30 \mathrm{~kg}$./fed. iron ore, $\mathrm{Zn}{ }_{1}=15 \mathrm{~kg}$. /fed., $\mathrm{Zn}{ }_{2}=20 \mathrm{~kg}$. /fed. zinc ore

Foliar addition $\mathrm{F}_{1}=50 \mathrm{ppm}, \mathrm{F}_{2}=100 \mathrm{ppm}$ iron-EDTA, $\mathrm{Zn}_{1}=50 \mathrm{ppm}, \mathrm{Zn}_{2}=100 \mathrm{ppm}$ Zinc-EDTA 
The results showed that total yield of sweet pepper surpassed significantly with higher dose of $\mathrm{Fe}$ treatment followed by higher dose of $\mathrm{Zn}$ treatment when compare to control, $\mathrm{Fe}_{1}$ and $\mathrm{Zn}_{1}$ treatments.

The lowest values of total yield observed with control treatment. The combination treatment (100ppm Fe EDTA+100 ppm zn EDTA) or (100ppm Fe EDTA+50 ppm Zn EDTA) gave the best values of yield and its components than all other treatments under study in both growing seasons. The results are in the same harmony of those obtained by Hatwar $\boldsymbol{e t}$ al. 2003.

This effect might be due to that micronutrients play a pivotal role in strengthening plant cell walls and translocation of carbohydrates leaves to other plant parts. Also, Hansch and Mendel, 2009 reported increase yields in chillies as related to iron nutrition may be due to its role in chlorophyll synthesis which led to enhancement of photosynthesis process.

Salinity stress due to drip irrigation with saline water significantly decreased fruit yield of sweet pepper. The decrease could be improved by foliar nutrients spray (Jabeen and Ahmed, 2009). In the same line, Shivaprasad et al., 2009 showed that application of micronutrients increased yield of chili which is mainly might be attributed to enhancing photosynthesis activity and accumulation of carbohydrates and essential auxins. Zn application also increased the yield of sweet pepper, this could be due to the influence of $\mathrm{Zn}$ to increase metabolism in plants. Also, the higher yield may be due to its better effect with other nutrients uptake (Shvaprasad et al., 2009 and Shil et al., 2013).

Table 6. Effect of micronutrients on fruits yield and quality of sweet pepper through growing autumn seasons.

\begin{tabular}{|c|c|c|c|c|c|c|c|c|c|}
\hline \multirow{2}{*}{$\begin{array}{l}\text { Charact } \\
\text { Meth. of } \\
\text { appl. }\end{array}$} & \multicolumn{3}{|c|}{ No. of fruits/plant } & \multicolumn{3}{|c|}{ Weight of fruits/ plant (g) } & \multicolumn{3}{|c|}{ Total yield (ton/fed.) } \\
\hline & Soil & Foliar & Mean & Soil & Foliar & Mean & Soil & Foliar & Mean \\
\hline Treat. & \multicolumn{9}{|c|}{2008} \\
\hline control & 4.33 & 6.00 & 5.17 & 105.83 & 160.07 & 132.95 & 1.986 & 2.319 & 2.153 \\
\hline $\mathrm{Fe}_{1}$ & 13.67 & 13.27 & 13.47 & 410.67 & 466.11 & 438.39 & 4.582 & 9.006 & 6.794 \\
\hline $\mathrm{Fe}_{2}$ & 14.67 & 15.00 & 14.84 & 646.07 & 675.33 & 660.70 & 7.114 & 9.299 & 8.207 \\
\hline $\mathrm{Zn}_{1}$ & 13.00 & 13.20 & 13.10 & 543.57 & 557.87 & 550.72 & 4.620 & 6.692 & 5.656 \\
\hline $\mathrm{Zn}_{2}$ & 13.13 & 15.17 & 14.15 & 553.10 & 642.12 & 597.61 & 6.738 & 6.740 & 6.739 \\
\hline $\mathrm{Fe}_{1}+\mathrm{Zn}_{1}$ & 13.47 & 13.77 & 13.62 & 488.55 & 610.76 & 549.66 & 9.391 & 9.780 & 9.586 \\
\hline $\mathrm{Fe}_{2}+\mathrm{Z}_{\mathrm{n} 2}$ & 14.67 & 15.33 & 15.00 & 651.58 & 782.82 & 717.20 & 9.737 & 9.789 & 9.763 \\
\hline $\mathrm{Fe}_{1}+\mathrm{Zn}_{2}$ & 13.77 & 14.50 & 14.14 & 565.34 & 718.42 & 641.88 & 9.491 & 9.553 & 9.522 \\
\hline $\mathrm{Fe}_{2}+\mathrm{Zn}_{1}$ & 13.67 & 15.67 & 14.67 & 596.30 & 799.17 & 697.74 & 9.658 & 9.898 & 9.778 \\
\hline Mean & 12.71 & 13.55 & & 506.78 & 601.41 & & 7.035 & 8.120 & \\
\hline \multicolumn{4}{|c|}{ L.S.D. at $5 \%$ for Treatments $=0.58$} & \multicolumn{3}{|c|}{$=37.74$} & \multicolumn{3}{|c|}{$=0.58$} \\
\hline \multicolumn{4}{|c|}{ Method of applications $=0.85$} & \multicolumn{3}{|c|}{$=41.12$} & \multicolumn{3}{|c|}{$=0.22$} \\
\hline \multicolumn{4}{|c|}{ Treat. X Method. = n.s } & \multicolumn{3}{|c|}{$=44.38$} & \multicolumn{3}{|c|}{$=0.70$} \\
\hline \multicolumn{10}{|c|}{2009} \\
\hline control & 4.33 & 5.67 & 5.00 & 109.73 & 155.10 & 132.42 & 2.107 & 2.317 & 2.212 \\
\hline $\mathrm{Fe}_{1}$ & 12.00 & 15.33 & 13.67 & 393.37 & 536.27 & 464.82 & 6.605 & 9.055 & 7.830 \\
\hline $\mathrm{Fe}_{2}$ & 15.00 & 16.00 & 15.50 & 585.28 & 650.53 & 617.91 & 7.210 & 9.155 & 8.183 \\
\hline $\mathrm{Zn}_{1}$ & 14.33 & 14.67 & 14.50 & 495.90 & 568.93 & 532.42 & 4.779 & 6.806 & 5.790 \\
\hline $\mathrm{Zn}_{2}$ & 13.83 & 15.00 & 14.42 & 506.82 & 594.67 & 550.75 & 7.017 & 7.517 & 7.267 \\
\hline $\mathrm{Fe}_{1}+\mathrm{Zn}_{1}$ & 15.67 & 16.00 & 15.84 & 593.90 & 626.27 & 610.09 & 7.505 & 9.515 & 8.510 \\
\hline $\mathrm{Fe}_{2}+\mathrm{Zn}_{2}$ & 16.00 & 17.00 & 16.50 & 795.83 & 857.27 & 826.55 & 9.744 & 10.055 & 9.900 \\
\hline $\mathrm{Fe}_{1}+\mathrm{Zn}_{2}$ & 15.33 & 16.67 & 16.00 & 622.27 & 707.80 & 665.04 & 9.354 & 9.704 & 9.529 \\
\hline $\mathrm{Fe}_{2}+\mathrm{Zn}_{1}$ & 15.67 & 17.27 & 16.47 & 640.33 & 911.67 & 776.00 & 9.559 & 9.815 & 9.687 \\
\hline Mean & 13.57 & 14.85 & & 527.05 & 623.17 & & 7.098 & 8.215 & \\
\hline \multicolumn{4}{|c|}{ L.S.D. at $5 \%$ for Treatments $=0.76$} & \multicolumn{3}{|c|}{$=37.74$} & \multicolumn{3}{|c|}{$=0.69$} \\
\hline \multicolumn{4}{|c|}{ Method of applications $=1.29$} & \multicolumn{3}{|c|}{$=41.12$} & \multicolumn{3}{|c|}{$=1.09$} \\
\hline \multicolumn{4}{|c|}{ Treat. X Method. = n.s } & \multicolumn{3}{|c|}{$=39.05$} & \multicolumn{3}{|c|}{$=0.81$} \\
\hline
\end{tabular}

Soil addition $\mathrm{Fe}_{1}=25 \mathrm{~kg}$./fed, $\mathrm{Fe}_{2}=30 \mathrm{~kg}$./fed. iron ore, $\mathrm{Zn}{ }_{1}=15 \mathrm{~kg}$. $/ \mathrm{fed} ., \mathrm{Zn}_{2}=20 \mathrm{~kg}$. $/ \mathrm{fed}$. zinc ore

Foliar addition $\mathrm{F}_{1}=50 \mathrm{ppm}, \mathrm{F}_{2}=100 \mathrm{ppm}$ iron-EDTA, $\mathrm{Zn}_{1}=50 \mathrm{ppm}, \mathrm{Zn}_{2}=100 \mathrm{ppm}$ Zinc-EDTA

\section{B.3. Effect of interaction:-}

The interaction effect as shown in Tables ( 5 and 6) revealed significant differences in fruit length, diameter and weight per plant in the first season only, while weight of fruit in the two growing seasons. Also number of fruits/plant have no significant differences among interaction treatments, while weight of fruits/plant and total yield gave the highest values significantly with interaction treatment 100 ppm Fe-EDTA + 50 ppm Zn-EDTA as 
foliar spray followed by 100 ppm Fe-EDTA + 100 ppm Zn-EDTA treatments. These results are true in both growing seasons. Interaction treatments $\mathrm{Fe}_{2}+$ $\mathrm{Zn}_{1}$ and $\mathrm{Fe}_{2}+\mathrm{Zn}_{2}$ respectively as foliar spray gave the highest values of total yield and its components than other treatments. The results are in the same trend of those obtained by Hatwar et al. 2003; Shivaprased et al., 2009; Ali et al., 2013 and Naga et al., 2013.

\section{Chemical composition:}

\section{C.1. method of application:-}

Results in Tables (7 and 8) indicated that foliar spray or soil addition methods of $\mathrm{Fe}$ and $\mathrm{Zn}$ application increased chemical composition contents of sweet pepper fruit significantly (vitamin C, protein, nitrogen, phosphorus, potassium, calcium and $\mathrm{Fe}$. While $\mathrm{Na}$ and $\mathrm{Cl}$ decreased with $\mathrm{Fe}$ and $\mathrm{Zn}$ application either as soil addition or as foliar spray. But $\mathrm{Zn}$ content in sweet pepper fruit not affected by method of application and has no significant difference between methods of application.

Foliar spray and soil addition of micronutrients promote chemical composition of various crop (Ali et al., 2013 on tomato). Foliar spray method surpassed than soil addition method and gave higher values of $\mathrm{N}, \mathrm{P}, \mathrm{K}, \mathrm{Ca}$ and $\mathrm{Fe}$ content and gave the lowest values of $\mathrm{Na}$ and $\mathrm{Cl}$ content. No significant differences were detected between methods of application on Zn content. Foliar spray application method of micronutrients caused a significant increase in vitamin $\mathrm{C}$ and protein content of fresh pepper fruits when compared to soil addition method. The least values of chemical composition content except $\mathrm{Na}$ and $\mathrm{Cl}$ content were obtained with spraying water or without addition (control treatments). The results are true in both growing seasons.

The results are in agreement with those obtained by Agrawal et al., 2010; Mahdi et al., 2011; Gurmani et al., 2012 and Ali et al., 2013 on tomato. Foliar spray enhancement might be due to that micronutrients play a pivotal role in strengthening plant cell walls and translocation of carbohydrates from leaves to other plant parts (Hatwar et al., 2003 and Anonymous, 2007). Also Kolota and Osinska, 2001 and Anonymous, 2004 revealed that foliar spray method surpassed than soil addition of nutrients because foliar spray deliver nutrients immediately to the tissues and organs of crop and increase quality and overcome the negative effect of stress conditions.

\section{C.2. Fe and $\mathrm{Zn}$ treatments:-}

Data presented in Tables (7 and 8) showed that chemical composition contents of vitamin C, Protein, $\mathrm{N}, \mathrm{P}, \mathrm{K}, \mathrm{Ca}, \mathrm{Fe}$ and $\mathrm{Zn}$ of sweet pepper fruits increased significantly with $\mathrm{Fe}$ or $\mathrm{Zn}$ application, except $\mathrm{Na}$ and $\mathrm{Cl}$ content decreased with $\mathrm{Fe}$ and $\mathrm{Zn}$ application. The chemical composition content increased with increasing rate of ( $\mathrm{Fe}$ and $\mathrm{Zn}$ ). Iron ore as soil application from $25 \mathrm{Kg}$. up to $30 \mathrm{~kg}$./Fed., while zinc ore from $15 \mathrm{~kg}$. up to $20 \mathrm{~kg}$./fed.. Also, with increasing foliar spray concentration for FeEDTA or Zn-EDTA from $50 \mathrm{ppm}$ up to $100 \mathrm{ppm}$ increased chemical composition content except $\mathrm{Na}$ and $\mathrm{Cl}$ content were decreased. The highest values of chemical composition of sweet pepper recorded with combination treatments $\left(\mathrm{Fe}_{2}+\mathrm{Zn}_{1}\right)$ and $\left(\mathrm{Fe}_{2}+\mathrm{Zn}_{2}\right)$ respectively except $\mathrm{Na}$ and $\mathrm{Cl}$ content decreased with $\mathrm{Fe}$ and $\mathrm{Zn}$ application significantly when compare to control treatment.

The results are in the same trend with those obtained by, Hakan et al., 2006. These results may be due to $\mathrm{Zn}$ nutritional status of plants which improve salt stress tolerance. Also, $\mathrm{Zn}$ nutrition reduce excess uptake of $\mathrm{Na}$ by roots in saline conditions. Iron plays an important role in promoting component of Ferrodoxin, an electron transport protein and is associated with chloroplast (Mahdi $\boldsymbol{e t}$ al., 2011). Also, higher dose of Fe-EDTA recorded higher assimilation of nutrients in fruits than lower dose.

\section{C.3. Effect of interaction:}

The results revealed in Tables (7 and 8) show that chemical composition content of sweet pepper fruits (vitamin C, Protein , N , P, K, Ca, Na , Cl, Fe and $\mathrm{Zn}$ ) are affected by interaction treatments. Interaction treatments showed significant differences among treatments. Also, interaction treatments increased values of chemical composition content significantly than control treatment in (Vitamin C, Protein, N, K, $\mathrm{P}, \mathrm{Ca}$ and $\mathrm{Fe}$ ), while the values decreased than control treatment in $(\mathrm{Na}$ and $\mathrm{Cl}$ content). These results are true in two growing seasons.

The highest values of chemical composition content obtained with interaction foliar spray treatment $\left(\mathrm{Fe}_{2}+\mathrm{Zn}_{1}\right)$ or $\left(\mathrm{Fe}_{2}+\mathrm{Zn}_{2}\right) 100$ ppm FeEDTA + 50 ppm Zn-EDTA and 100 ppm Fe-EDTA +100 ppm Zn-EDTA respectively. $\mathrm{Na}$ and $\mathrm{Cl}$ content gave the lowest values with this treatment, while this treatment has no significant effect on $\mathrm{Zn}$ content in sweet pepper fruits. These results are true in both growing seasons. Iron is necessary for photosynthesis and is present as an enzyme cofactor in plants, iron import from the metabolic pathways that lead to the assembly of Fe into proteins (Briat $\boldsymbol{e t}$ al., 2007; Ali et al., 2013 and Naga et al., 2013).

\section{EDTA}

Iron plays essential roles in the metabolism of chlorophylls (Sultana et al., 2001).

The combine application of iron $100 \mathrm{ppm}+$ zinc 50 ppm was most effective for improving V.C. content of tomato (Abdel-Mawgoud et al., 2011) foliar application resulted in higher chlorophyll contents of green bean. 
Table 7. Effect of some micronutrients on chemical and quality of sweet pepper through growing autumn seasons.

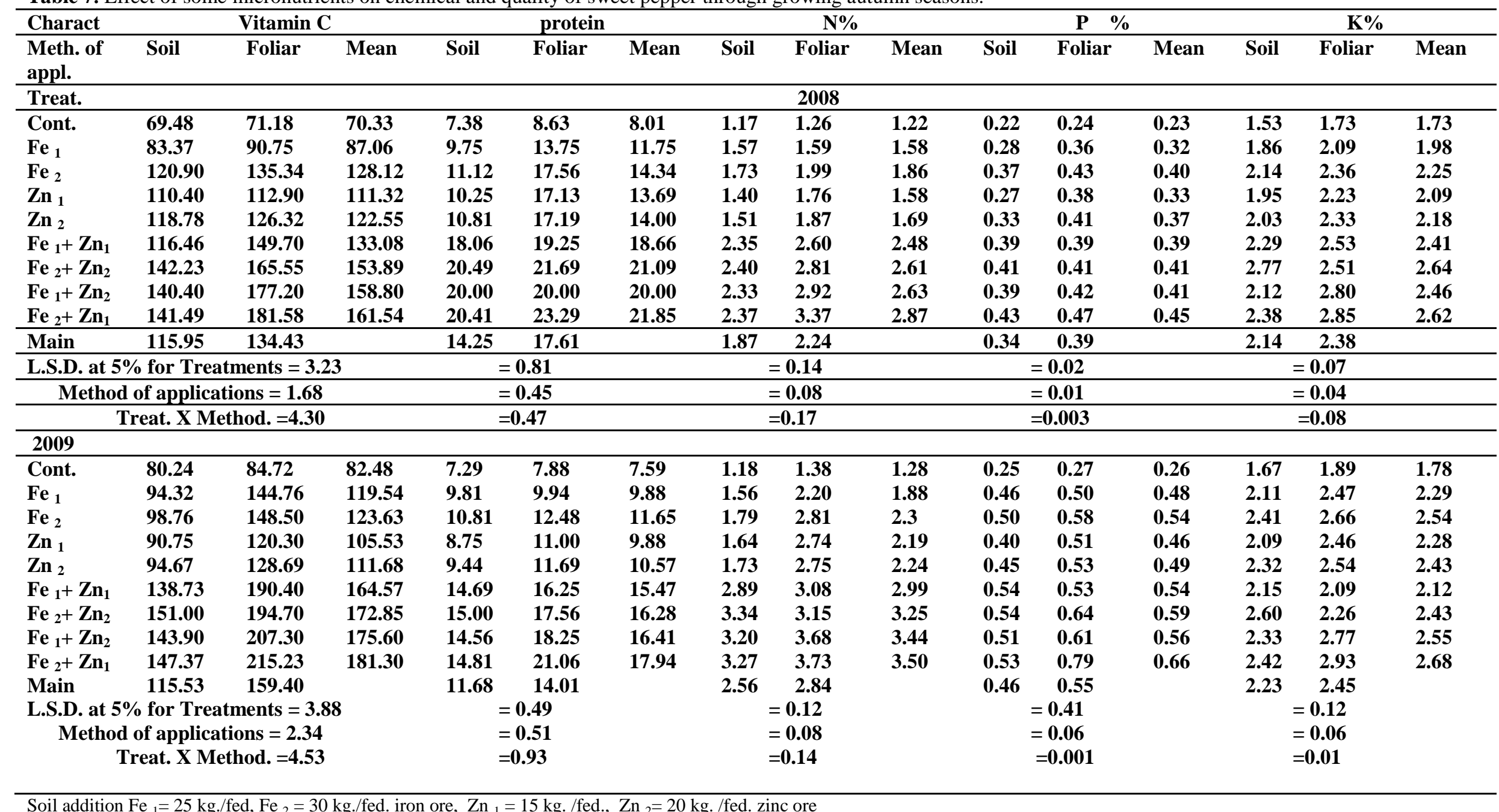

Foliar addition $\mathrm{F}_{1}=50 \mathrm{ppm}, \mathrm{F}_{2}=100 \mathrm{ppm}$ iron-EDTA, $\mathrm{Zn}_{1}=50 \mathrm{ppm}, \mathrm{Zn}_{2}=100 \mathrm{ppm}$ Zinc-EDTA 
Table 8. Effect of micronutrients on chemical and quality of sweet pepper through growing autumn seasons.

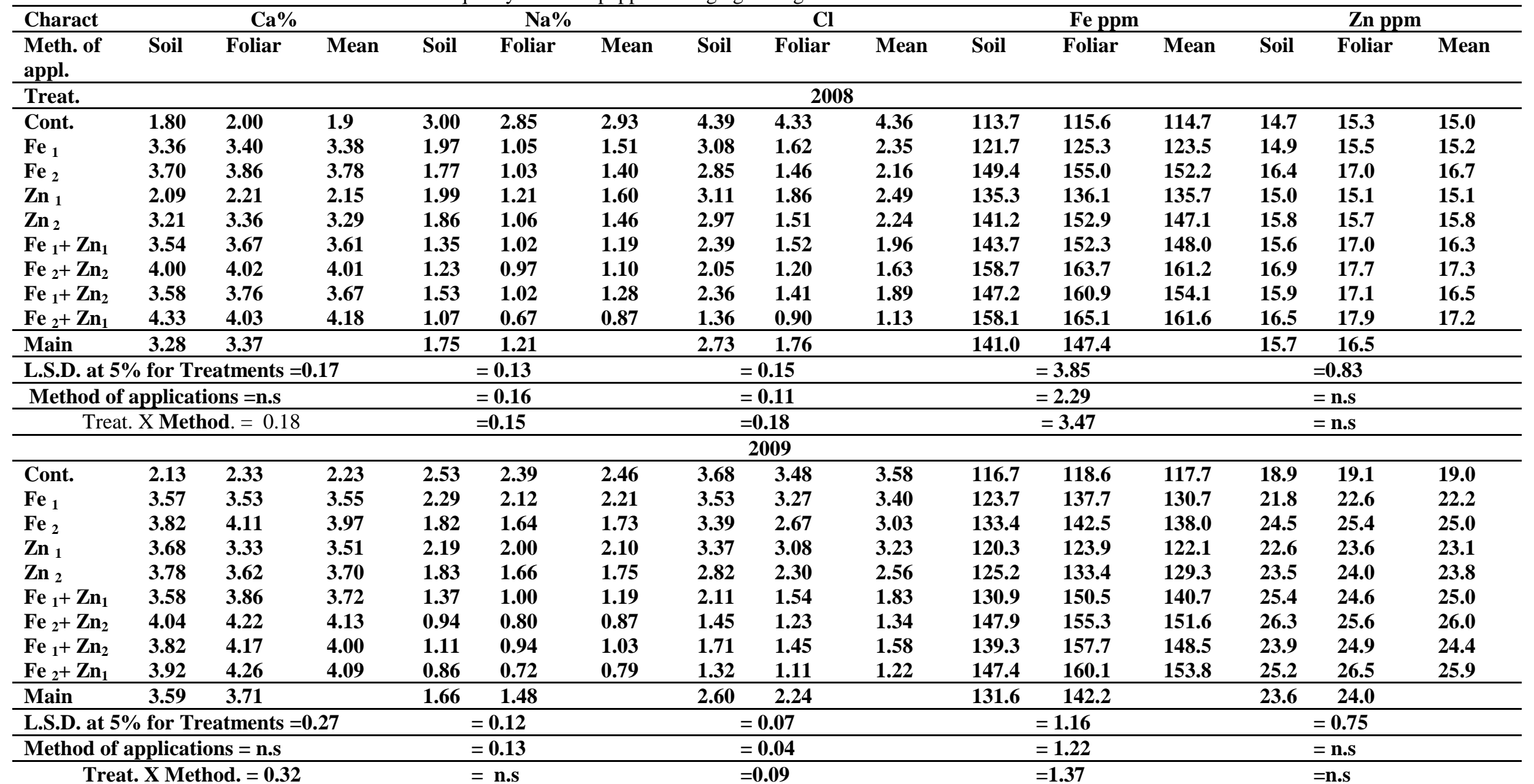

Soil addition $\mathrm{Fe}_{1}=25 \mathrm{~kg}$./fed, $\mathrm{Fe}_{2}=30 \mathrm{~kg}$./fed. iron ore, $\mathrm{Zn}_{1}=15 \mathrm{~kg}$. /fed., $\mathrm{Zn_{2 }}=20 \mathrm{~kg}$. /fed. zinc ore

Foliar addition $\mathrm{F}_{1}=50 \mathrm{ppm}, \mathrm{F}_{2}=100 \mathrm{ppm}$ iron-EDTA, $\mathrm{Zn}_{1}=50 \mathrm{ppm}, \mathrm{Zn}_{2}=100 \mathrm{ppm} Z$ inc-EDTA 
The results in the same harmony of those obtained by (Agrwal et al., 2010 and Mahdi et al., 2011). The importance of $\mathrm{Zn}$ may be due to improving salt stress tolerance, controlling the permeability of root cell membranes, also $\mathrm{Zn}$ reduces excess uptake of $\mathrm{Na}$ by roots in saline conditions (Tamilselvi et al., 2002 and Shil et al., 2013).

\section{Conclusions}

Under South Sinai conditions, highly calcareous and saline soil which is irrigated with drip irrigation system from well its salinity about $3700 \mathrm{ppm}$. The sweet pepper (California Wonder) gave the best values of growth characters, yield and its components and chemical composition with application micronutrients (100 ppm Fe-EDTA + 50 or 100 ppm Zn-EDTA) under Ras Sudr condations.

\section{References}

Abdel-Mawgoud, A.M.R; El-Bassiouny, A.M.; Ghoname, A. and S.D. Abou-Hussein, 2011. Foliar application of amino acids and micronutrients enhance performance of green bean crop under newly reclaimed land conditions. J. Basic \& Appl. Sci., 5(6): 51-55.

Ahmad, R. and R. Jabeen, 2005. Foliar spray of mineral elements antagonistic to sodium: a technique to induce salt tolerance in plants growing under saline conditions. Pak. J. Bot., 37: 913- 920.

Ahmed, A.A.; Abd El-Baky, M.M.H.; Zaki, M.F. and F. S. Abd El-Aal, 2011. Effect of foliar application of active yeast extract and zinc on growth, yield and quality of potato plant (Solanum tuberosum L.). J. of Appli. Sci. Res., 7(12): 2479-2488.

Agrawal, B.; Shrivastava, A. and N. Harmukh, 2010. Effect of irrigation methods and micronutrients on nutrient uptake of tomato F1 hybrid avinash-2. Int. J. Curr. Trends Sci. Tech., 1: 20-26.

Ali R., G.1.; Jalal, U.D.; Rani, A.S.; Kashif, W.; Ahmed, K. and T.H Adya, 2012. Soil application of zinc improves growth and yield of tomato. I. J. of Agri. \& Biol. ISSN Print: 1560-8530.

Ali, S.; Hafiz, U.J.; Rana N.U. R.; Irfan A. S.; Muhammad S.N.; Muhammad Z.S.; Dawood, A.S. and A. N Muhammad, 2013. Foliar application of some macro and micro nutrients improves tomato growth, flowering and yield. Int. J. of Bio. Vol. 3, No. 10, 280-287.

Anonymous, 2004. Chillies Home Page. Global Commercial Services for the Spice. Industry. Spizes.Com. Quest Inter. http://www.Spizes.com.

Anonymous, 2007. Micronutrient fertilizers: Fetrilon Combi, a foliar application for vegetables. http://www.agnova.com.au/resources/FetrilonCombi-guide.
A.O.A.C., 1990. Official Methods of Analysis. 15th ed., Association of Official Analytical Chemists, Washington, D.C., USA.

Briat, J.F.; Curie, C. and F. Gaymard, 2007. Iron utilization and metabolism in plants. Curr. Opin. Pl. Biol., 10: 276-282.

Brown, J.D. and O. Lilliland, 1964. Rapid determination of potassium and sodium in plant materials and soil extracts by flame photometer. Proc. Amer. Soc. Hort. Sci., 48:341-346.

Chapman, H.D. and P.F. Pratt, 1982. Methods of Plant Analysis, I. Methods of Analysis for Soil, Plant and Water. Chapman Publishers, Riverside, California, USA

Ejaz, M.; Waqas, R.; Butt, M.; Rehman, S.U. and A. Manan, 2011. Role of macro-nutrients and micronutrients in enhancing the quality of tomato. Int. J. Agron. Vet. Med. Sci., 5:401-404.

El-Bassiony, A.M.; Fawzy, Z.F.; Abd El-Samad, E.H. and G.S. Riad, 2010. Growth, yield and fruit quality of sweet pepper plants (Capsicum anпиит L.) as affected by potassium fertilization. J. of Amer. Sci., 2010; 6 (12): 722-729.

El- Fouly, M.M. and E.A.A. Abou El-Nour, 1998. Registration and use of foliar fertilizers in Egypt. Proc. Sym. Foliar Fertilization: A Tech. to Impr. Prod. and Decr. Poll. 10-14 Dec. NRC. Cario. Egypt, pp. 1-5.

Gomez, K.A. and A.A. Gomez, 1984. Statistical procedures for agriculture research. 2nd ed. Willey Inter Sci. Publ., pp: 323-357.

Gurmani, A.R.; Din, J.U.; Khan, S.U.; Andaleep, R.; Waseem, K.; Khan, A. and H. Atullah, 2012. Soil application of zinc improves growth and yield of tomato. Int. J. Agri. Boil., 14:91-96.

Hakan, A. K.; Abak, M.; ZT-R, L. and S. Akmak, 2006. The effect of zinc on growth and shoot concentrations of sodium and potassium in pepper plants under salinity stress. Turk. J. Agri. For 30: 407-412.

Hänsch, R. and R.R. Mendel, 2009. Physiological functions of mineral micronutrients $(\mathrm{Cu}, \mathrm{Zn}, \mathrm{Mn}$, $\mathrm{Fe}, \mathrm{Ni}, \mathrm{Mo}, \mathrm{B}, \mathrm{Cl})$. Current Opinion in Plant Biol., 12: 259-266.

Hatwar, G.P.; Gondane, S.U.; Urkude, S.M. and O.V. Gahukar, 2003. Effect of micronutrients on growth and yield of chilli. J. Soil Crops, 13:123125.

Huphries, E.C., 1965. Mineral components and ash analysis, modern methods of plant analysis edited by Peach, k. and Tracey, M.V. springer verlag, Berlin, 1:468.

Jabeen, R. and R. Ahmad, 2009. Alleviation of the adverse effects of salt stress by foliar application of sodium antagonistic essential minerals on cotton (Gossypium hirsutum). Pak. J. Bot., 41(5): 2199-2208.

Jachson, M.A., 1967. Soil chemical analysis prentice Hall press, New Delhi, India.

Johnson, C. M. and A. Uirich, 1959. Analytical 
methods for use in plant analysis, U. S. Dept. Agri. Calf. Univ., Agri. Inform. Bull., 766.

Kolota, E. and M. Osinska, 2001. Efficiency of foliar nutrition of field vegetables grown at different nitrogen rates. Acta Hort., 563: 87-91.

Mahdi B., Piri I.; Tavassoli, A.; Esmaeilian,Y. and H. Gholami, 2011. Effect of water stress and micronutrients (F A. e, $\mathrm{Zn}$ and $\mathrm{Mn}$ ) on chlorophyll fluorescence, leaf chlorophyll content and sunflower nutrient uptake in Sistan region. Afri. J. of Agri. Res. Vol. 6(15), pp. 3526-3531.

Malawadi, M. N., 2003. Effect of secondary and micronutrients on yield and quality of chilli (Capsicum annuum L.). M.Sc. (Agri.) Thesis, Univ. Agric. Sci., Dharwad (India).

Muhammad A. and A. Rafiq, 2011. Foliar application of some essential minerals on tomato (Lycopersicon Esculentum) plant grown under two different salinity reigns. Pak. J. Bot., 43(3): 1513-1520.

Naga S. K.; Swain S K; Sandeep V., and B. Raju, 2013. Effect of foliar application of micronutrients on growth parameters in tomato (Lycopersicon esculentum mill.). Dis. J. of Agri. and Food Sci. 1(10): 146-151.

Piper, C. S., 1950. Soil and plant analysis. Univ. Adelaide. 258-275. Inter. Sci. Publ., Inc. New Yourk.

Richards, L.F., 1954. Diagnosis and improvement of saline and alkaline soil. Agri. Hand Book, U.S.A., 60.

Rowel, D.L., 1994. Soil science methods and applications. J. of Agri. Sci. 123 Issue 03 , pp 419-419. New York.

Said A. Sh.; Zakaria F. F., and R. H. El-Ramady,
2012. Response of cucumber plants to foliar application of chitosan and yeast under green house conditions. Austr. J. of Basic and Appli. Sci., 6(4): 63-71

Savitha, H.R., 2008. Effect of iron-EDTA on yield and quilty of red chilli (Capsicum annuum L.) in a calcareous vertisol of zone-8 of karnataka. M. Sc. (Agri.) Thesis, Univ. Agric. Sci., Dharwad 580635

Sayed, R. M., 2011. Zinc in crop production and interaction with phosphorus. Austr. J. of Basic and Appli. Sci, 5(9): 1503-1509.

Shil, N.C.; Naser, H. M.; Brahma, S., Yousuf, M. N. and M. H. Rashid, 2013. Response of chili (Capsium annuum L.) to zinc and boron application. J. Agril. Res. 38(1): 49-59.

Shivaprasad, M.; Chittapur, B.M.; Tatagar M.H. and R.K. Mesta, 2009. Yield and quality of chilli (Cv. Bydagi dabbi) as influenced by secondary and micronutrients. Karnataka J. Agric. Sci., 22 (5):1090-1092.

Singh HM, and JK.Tiwari, 2013. Impact of micronutrient spray on growth, yield and quality of tomato (Lycopersicon esculentum Mill). Hort. Flora Res. Spectrum. 2(1), 87-89.

Sultana, N.; Ikeda, T. and M.A. Kashem, 2001. Effect of foliar spray of nutrient solutions on photosynthesis, dry matter accumulation and yield in seawater-stressed rice. Envirn. And Exper. Bot., 46: 129-140.

Tamilselvi, P.; Vijayakumar, R.M. and P. Nainar, (2002). Studies on the effect of foliar application of micronutrients on growth and yield of tomato (Lycopersicon esculentum Mill). Cv. PKM-1. South Ind. Hort., 53 (1-6) : 46-51. 


\title{
"استجابة الفلقل لمصادر مختلفة من العناصر الصغرى على النمو و المحصول و المحتوى الكيميائي تحت ظروف رأس سدر"
}

\section{شادية بسطروس داود يوسف}

\author{
مركز بحوث الصحراء بالمطرية - القاهرة- مصر
}

أقيمت تجربتان حقليتان بمحطة بحوث رأس سدر، محافظة جنوب سيناء خلال موسمي الزراعة الخريفي المتعاقبة لعامي 2008 و 2009

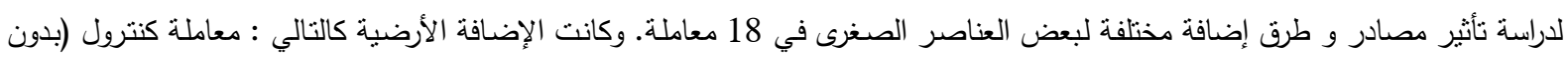

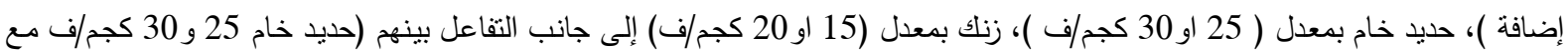

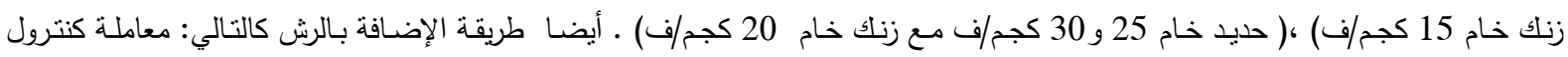

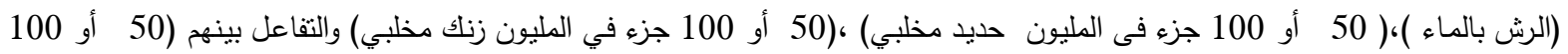

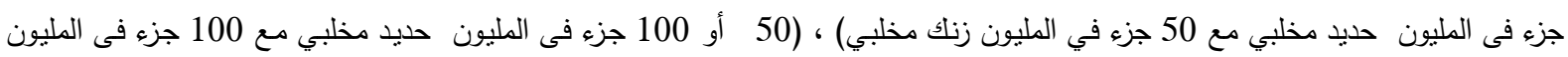
زنكك مخلبي) على النمو (طول النبات، عدد الأفرع، مساحة الأوراق، الوزن الطازج و الجاف للنبات والكلوروفيل) والمحصول ومكوناته (الوزن

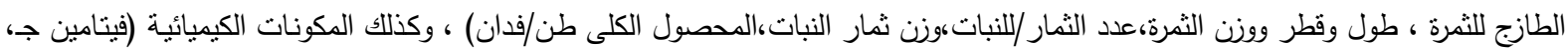

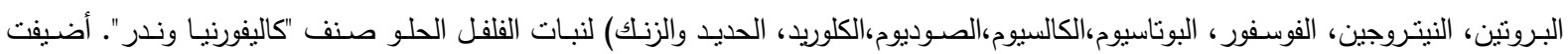

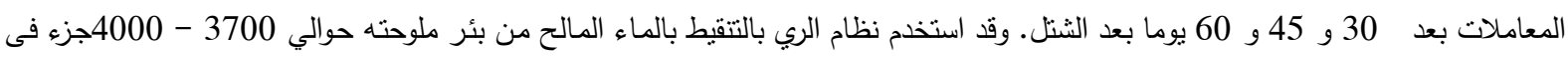
المليون ، وتم توزيع المعاملات فى قطع منشقة مرة واحدة في ثلاث مكررات.

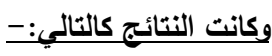

1- أظهرت النتائج أن طريقتي الإضـافة لعناصر الحديد والزنك (الإضافة الأرضية والرش الورقي) أعطت زيادة معنوية عن معاملات

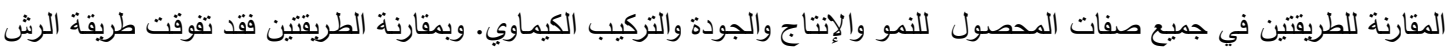

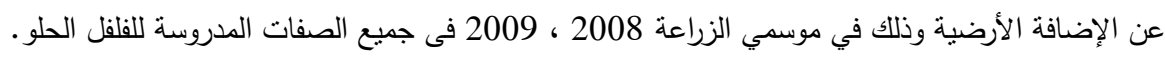

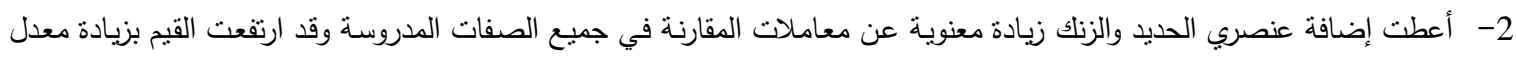

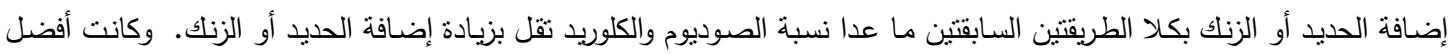
نتيجة بالنسبة للعناصر هي ش الحديد + الزنكك بمعدل 100 + 100 جزء فى المليون وأيضا 100 + 50 جزء في المليون بالنسبة الكادية للعنصرين على النوالي.

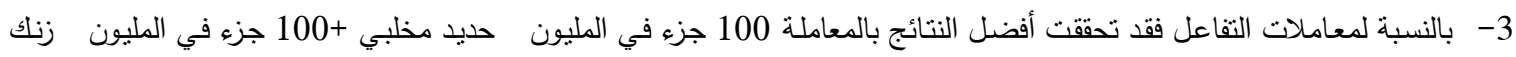

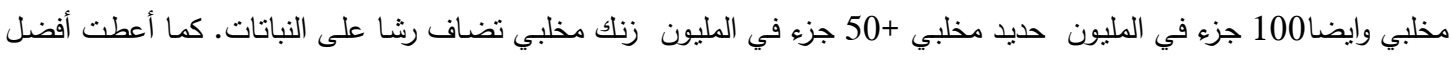
الصفات بالنسبة للنمو والإتناج والجودة والتزكيب الكيماوي.

عند زراعة الفلفل الحلو صنف كاليفونيا وندر تحت ظروف الأرض الملحية الكلسية والري بالتنقيط بالماء المالح في حدود 3700-4000

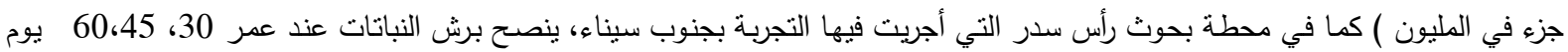

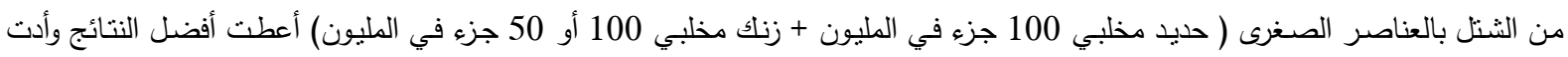
لتحسين صفات النمو والإنتاج ومكوناته والنركيب الكيماوي خلال موسمي النمو الخريفي 2008، 